\title{
SOCIAL FUNCTIONING OF ELDERLY PEOPLE LIVING IN RURAL AREAS
}

\section{FUNKCJONOWANIE SPOŁECZNE LUDZI STARSZYCH ZAMIESZKUJĄCYCH OBSZARY WIEJSKIE}

\author{
Małgorzata Dziechciażi ${ }^{1(A, B, C, D, G)}$, Jarosław Chmielewski ${ }^{2(A, B, C, D, E)}$, \\ Magdalena Florek-Łuszczki ${ }^{3(\mathrm{~A}, \mathrm{D}, \mathrm{E}, \mathrm{F})}$, Małgorzata Anna Czarny-Działak ${ }^{4(\mathrm{~B}, \mathrm{C}, \mathrm{E}, \mathrm{F})}$, \\ Jarogniew J. Luszczki ${ }^{5(D, E, F, G)}$
}

${ }^{1}$ Health Care Institute, State School of Higher Vocational and Economic Education in Jaroslaw, Poland ${ }^{2}$ Institute of Environmental Protection - National Research Institute in Warsaw, Poland

${ }^{3}$ Department of Medical Anthropology, Institute of Rural Health in Lublin, Poland ${ }^{4}$ Faculty of Medicine and Health Sciences, The Jan Kochanowski University in Kielce, Poland

${ }^{5}$ Department of Pathophysiology, Medical University of Lublin, Poland

Authors' contribution Wkład autorów: A. Study design/planning zaplanowanie badań B. Data collection/entry zebranie danych C. Data analysis/statistics dane - analiza i statystyki D. Data interpretation interpretacja danych E. Preparation of manuscript przygotowanie artykułu F. Literature analysis/search wyszukiwanie i analiza literatury G. Funds collection zebranie funduszy
Tables: 0

Figures: 6

References: 22

Submitted: 2018 March 13

Accepted: 2018 Jun 15

\section{Summary}

Background. The aim of this work was to assess social functioning of elderly people living in rural areas.

Material and methods. The authors used own interview questionnaire to collect the data. The study was conducted in 504 citizens, older than 65 years, from eight villages.

Results. Women were more frequently widowed than men, had low educational level and lived alone. As most responses showed (51.98\%), the received benefits did not cover the respondents' current needs and 5.95\% of them claimed that they were insufficient. The remaining respondents, i.e. $42.06 \%$, stated that the available resources fulfilled their needs. The respondents would also point to family's aid $(n=411 ; 81.55 \%)$ or spouse's aid $(n=147$; $29.56 \%)$. Only 37 people benefited from social care $(n=504 ; 7.34 \%)$, of which $24(64.86 \%)$ claimed that the help provided by social care was insufficient.

Conclusions. Old women in rural areas tend to live alone more frequently, are widowed and have lower level of education than men. The received financial benefits do not fully cover current needs of older residents of rural areas regardless of sex. Among people of over 65 years living in rural areas, the majority (81.55\%) would point to family support and only $2.18 \%$ indicated social care as a source of income.

Keywords: social functioning, seniors, rural areas

\section{Streszczenie}

Wprowadzenie. Celem pracy była ocena funkcjonowania społecznego osób w podeszłym wieku zamieszkujących obszary wiejskie.

Materiał i metody. Dane w badaniu zostały zebrane przy pomocy autorskiego kwestionariusza. Badania ankietowe przeprowadzono wśród 504 obywateli ośmiu wsi u osób powyżej 65 roku życia.

Wyniki. Kobiety były częściej wdowami niż mężczyźni, miały niski poziom wykształcenia i żyły samotnie. Zgodnie z większością odpowiedzi (51,98\%), otrzymane świadczenia nie pokrywają bieżących potrzeb, 5,95\% badanych stwierdziło, że zasoby były niewystarczające. Pozostała liczba respondentów 42,06\% stwierdziła, że zasoby zaspokajają ich potrzeby. Najczęściej wskazywano na pomoc rodziny $(\mathrm{n}=411 ; 81,55 \%)$ lub współmałżonka $(\mathrm{n}=147,29,56 \%)$. Tylko 37 osób korzystało z pomocy społecznej $(n=504 ; 7,34 \%)$, spośród których 24 osoby $(64,86 \%)$ twierdziły, że pomoc zapewniona przez opiekę społeczną jest niewystarczająca.

Wnioski. Starsze kobiety żyjace na obszarach wiejskich częściej mieszkaja samotnie, sa wdowami i mają niższe wykształcenie niż mężczyźni. Wszystkie otrzymywane korzyści finansowe nie w pełni pokrywają bieżące potrzeby starszych mieszkańców obszarów wiejskich bez względu na płeć. Wśród osób powyżej 65 roku życia mieszkających na obszarach wiejskich większość (81,55\%) wskazała pomoc rodzinną, a 2,18\% wskazało opiekę społeczną jako źródło wsparcia.

Słowa kluczowe: funkcjonowanie społeczne, seniorzy, obszary wiejskie

Dziechciaż M, Chmielewski J, Florek-Łuszczki M, Czarny-Działak MA, Łuszczki JJ. Social functioning of elderly people living in rural areas. Health Prob Civil. 2018; 12(3): 209-216. https://doi.org/10.5114/hpc.2018.76746

Address for correspondence / Adres korespondencyjny: Jarogniew J. Łuszczki, Department of Pathophysiology, Medical University in Lublin, Jaczewskiego 8, 20-090 Lublin, Poland, e-mail: jarogniew.luszczki@umlub.pl, phone: +48814486500

Copyright: (C) Pope John Paul II State School of Higher Education in Biała Podlaska, Małgorzata Dziechciaż, Jarosław Chmielewski, Magdalena Florek-Łuszczki, Małgorzata Anna Czarny-Działak, Jarogniew J. Łuszczki. This is an Open Access journal, all articles are distributed under the terms of the Creative Commons Attribution-NonCommercial-ShareAlike 4.0 International (CC BY-NC-SA 4.0) License (http://creativecommons.org/licenses/by-nc-sa/4.0/), allowing third parties to copy and redistribute the material in any medium or format and to remix, transform, and build upon the material, provided the original work is properly cited and states its license. 


\section{Introduction}

The situation of seniors living in rural areas is determined by various factors, including family and housing conditions, material security, health condition, possible access to social care and medical services [1]. According to Iwański, seniors in rural areas create a specific social stratum, mostly consisting of poor, scattered around people, often without social care or other state aid [2]. The author draws attention to the difference between the highest pension paid by Social Insurance Company (ZUS) and Farmer's Social Security Fund (KRUS), which in 2009 totalled 765 PLN, which indicates that retirees in rural areas have much lower financial resource [2]. The disabled elderly living in rural areas experience various barriers and limitations [2-4], generally resulting from inappropriate infrastructure, personal social care and difficult financial situation $[5,6]$. The scattered location of the housing causes that seniors living in rural areas experience troubles with shopping and access to cultural assets [2,6]. Moreover, housing infrastructure of seniors in rural areas is worse than in urban ones. Many seniors reside in non-renovated and expensive to maintain houses, without water, sewer and gas installations, telephone and other devices providing comfortable living [2, 7]. Older residents of rural areas have more difficult access to support offered by psychologists or guided self-help [8]. Moreover, it is much more challenging to provide institutionalised aid as it is not accepted and considered to be humiliating. Additionally, the problem with financial aid is related to the income obtained from comparative fiscal hectare [1]. The work aimed to assess the social functioning of the elderly living in rural areas.

\section{Material and methods}

The research data for socio-demographic, financial and social support were collected using the authors' interview questionnaire. This study was carried out in 504 citizens, older than 65 years, from eight villages of Podkarpacie Province. The statistical analysis was completed using STATISTICA 6.0 PL software. The level of significance was set up at $\mathrm{p}<0.05$. The Kendall rank correlation coefficient, Kolmogorov-Smirnoff, Pearson's chisquared ( $\chi 2)$ tests and Kruskal-Wallis one-way analysis of variance followed by Dunn's test were used.

\section{Results}

The proportional ratio of men and women for every age category was similar. The most significant differences were among men and women between 66 and 70 years of age $(p<0.05)$ (fig. 1).

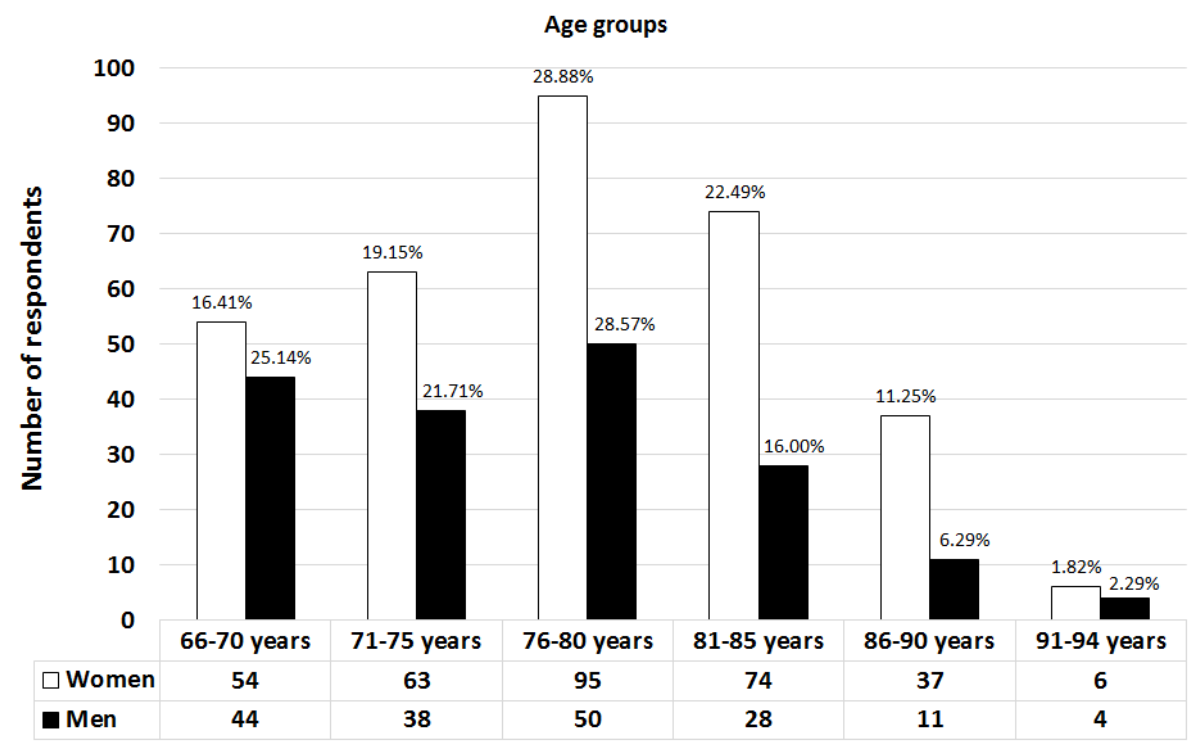

Figure 1. Age vs. sex of the test groups $(\mathrm{N}=504)$ 
The age of women was significantly higher than that of men $(p<0.001)$ (fig. 2).

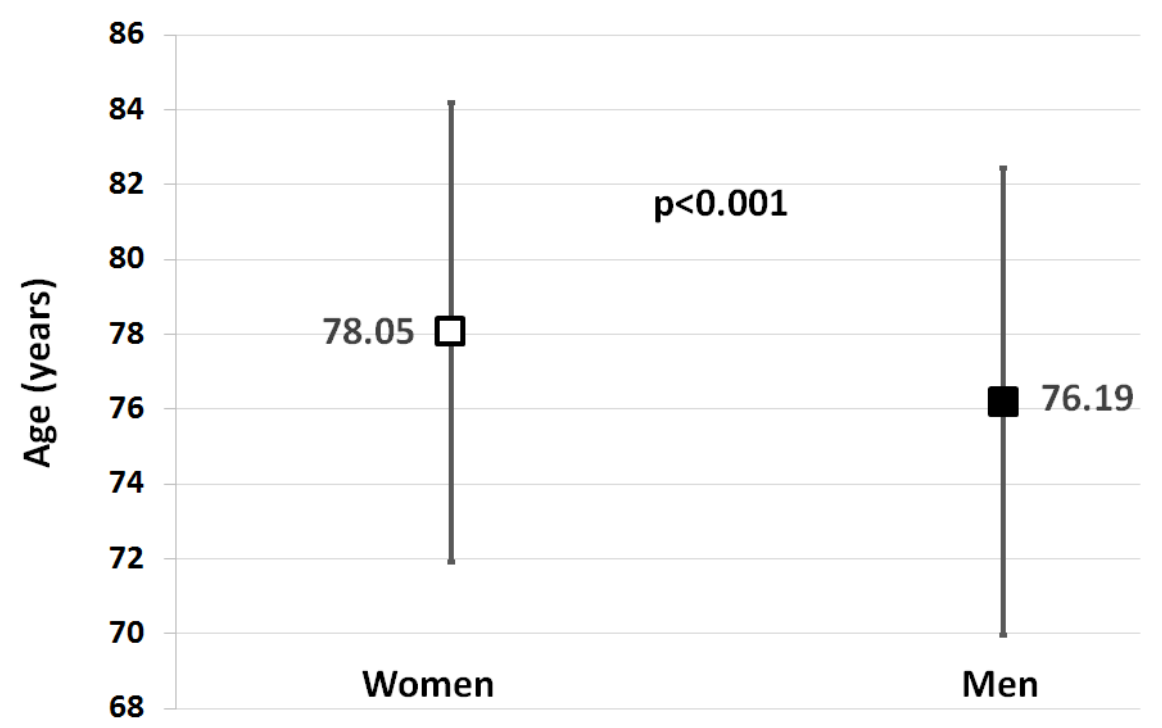

Figure 2. Sex vs. mean average and standard deviation of age $(\mathrm{N}=504)$

The differentiation of marital status between women and men was observed within the investigated population. Men would more often be married than women ( $\mathrm{n}=141 ; 80.57 \%$ vs. $\mathrm{n}=118 ; 35.87 \%)$, and single ( $n=6 ; 3.43 \%$ vs. $n=3 ; 0.91 \%)$. On the other hand, women more often declared being widowed ( $n=206 ; 62.61 \%$ vs. $\mathrm{n}=27 ; 15.43 \%)$. Significant differences were observed between married men $(\mathrm{p}<0.001)$, and widowed women $(\mathrm{p}<0.001)$ (fig. 3).

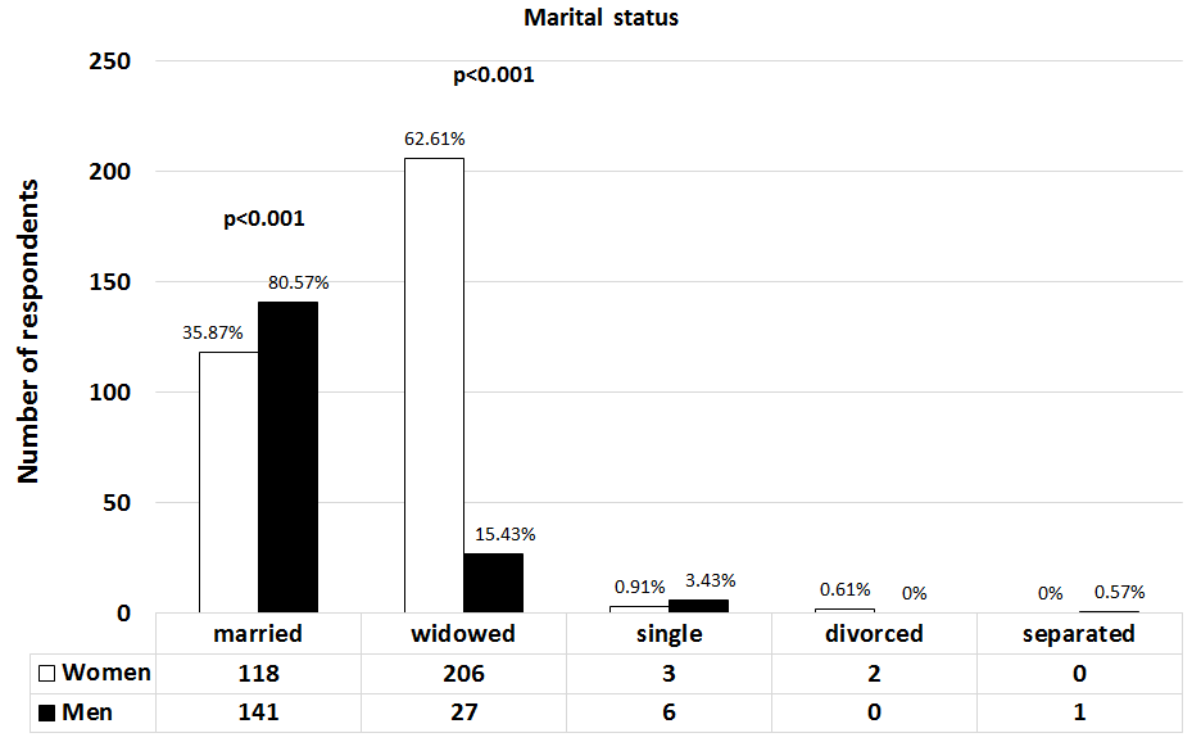

Figure 3. Marital status vs. sex ( $\mathrm{N}=504)$

On average, the widowed and single respondents were the oldest (79.36 and 79.00 respectively), followed by those who were divorced (75.55), and in separation (70.00). The average age of the married persons was 75.63 years. The age difference in the married, widowed and singles categories was significant at p<0.01 (fig. 3 ). 
As regards the educational level, women would significantly more often than men declare incomplete primary education and would rarely have a vocational education $(\mathrm{p}<0.001)$ (fig. 4).

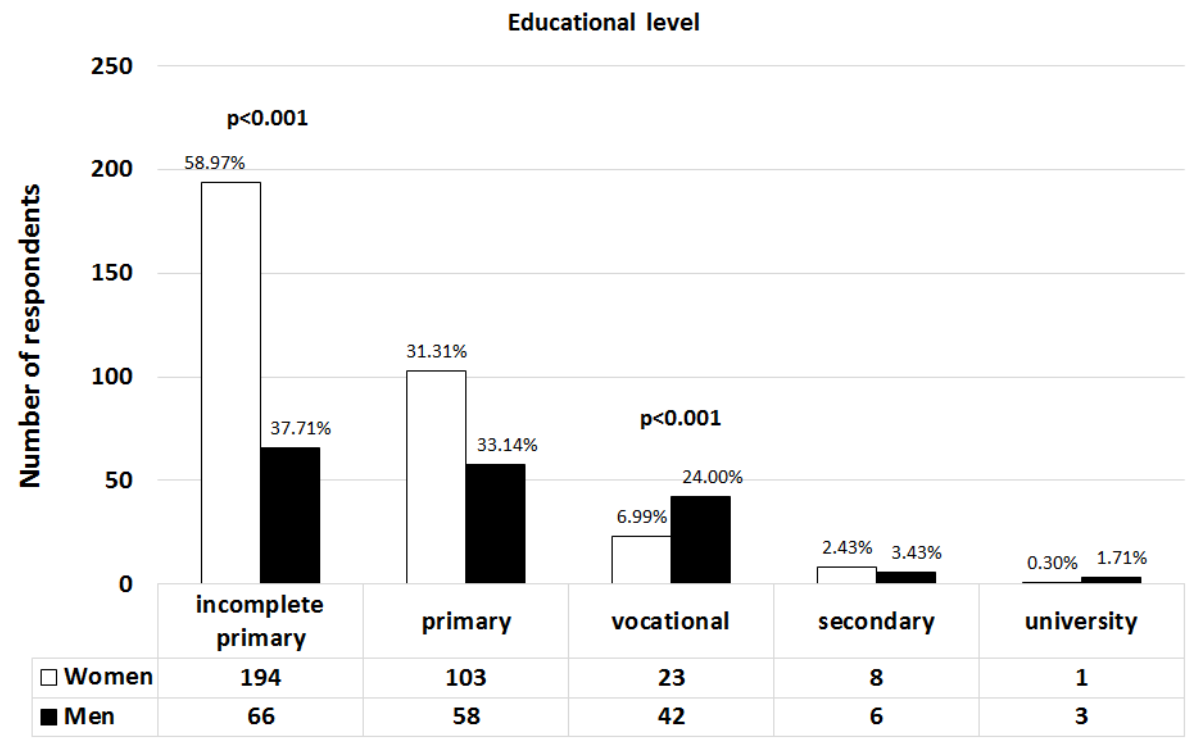

Figure 4. Education level of the tested groups vs. sex ( $\mathrm{N}=504)$

While analysing the age of the examined people with regard to their educational level, it was found that the respondents with incomplete primary education (average 79.74) and primary education (77.00) were older than people with secondary education (72.14) and a university degree (72.25). The youngest group consisted of the persons with vocational education (70.54) (fig. 4). The Kendall rank correlation coefficient test revealed a relationship between age and the level of education of the tested respondents $(\tau=-0.3498 ; p<0.001)$. Younger people had higher educational level than the older ones.

For the vast majority of respondents ( $\mathrm{n}=486$; $96.43 \%)$, the pension was the primary source of income and for the remaining ones $(n=18 ; 3.57 \%)$ - illness benefits. Only one person $(0.20 \%)$ admitted to receiving additional employment income in the whole group of the respondents. Differences between women and men concerning the source of income were not statistically significant $(\mathrm{p}>0.10)$.

As most frequently given responses (51.98\%) show, the received benefits did not cover the respondents' current needs, and only 5.95\% assured that the resources were insufficient. The remaining respondents (42.06\%) stated that resources fulfilled their needs. The received benefits were insufficient to cover current needs for a large number of men $(n=84 ; 48.0 \%)$ and women $(n=178 ; 54.1 \%)$, and for $6.38 \%(n=21)$ women and $5.14 \%(n=9)$ men, they were completely insufficient. The received benefits fully covered the needs of $39.51 \%$ ( $n=130)$ women and $46.86 \%$ (n=82) men. No significant differences were observed between women and men with regard to the received benefits which covered current needs ( $p>0.10)$.

The study rated the housing conditions using a four-grade scale. $28.17 \%(\mathrm{n}=142)$ of the surveyed persons rated them as "very good", 46.43\% (n=234) of the respondents would classify them as "good". The "average" category was pointed to by $23.61 \%(n=119)$ of the interviewees, and $1.79 \%(n=9)$ stated that they resided in "bad" housing conditions. No significant differences between men and women as for housing conditions were observed ( $\mathrm{p}>0.10)$. Both women and men frequently pointed to "good" housing conditions (nearly 50\% of indications).

A vast majority of the respondents ( $n=329 ; 65.28 \%$ ) lived with their families, $23.21 \%$ ( $n=117$ ) lived with their spouses, $11.31 \%(n=57)$ lived alone and only $0.20 \%(n=1)$ lived with people who were not related. Although women lived with their family more frequently than men, the difference was not statistically significant. A significant difference was observed in women who more often lived alone than men $(\mathrm{p}<0.001)$, and rarely with spouses ( $\mathrm{p}<0.001)$ (fig. 5). 


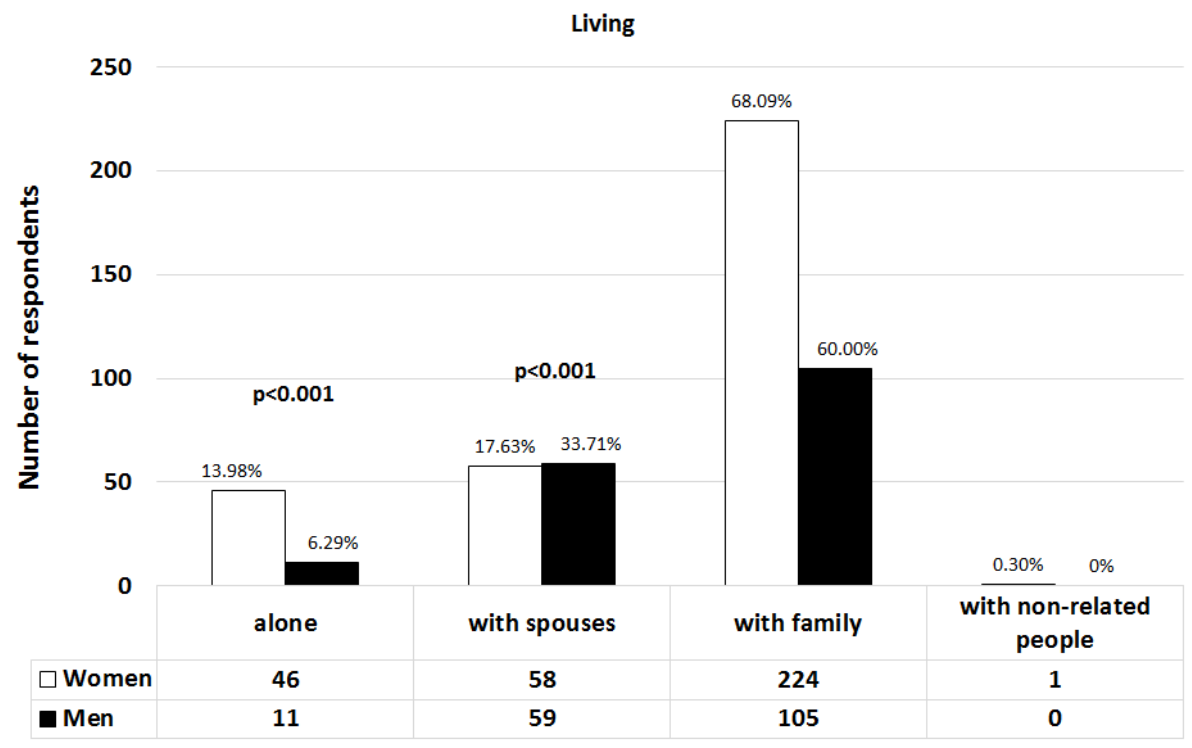

Figure 5. Living conditions of the examined respondents ( $N=504)$

The respondents living with spouses were the youngest (average 76.40). They were followed by those who were older and living with family (77.43), those living alone (79.28), and with non-related people (81.00), respectively. The Kruskal-Wallis one-way analysis of variance indicated the existence of statistically significant age difference related to the living condition of the test group (the analysis excluded one person living with non-related people) $-\mathrm{H}(2, \mathrm{~N}=$ $503)=5.35 ; \mathrm{p}<0.05)$. The Dunn's post-hoc test showed that all differences were statistically significant $(\mathrm{p}<0.01)$.

When asked whom they turn to to receive financial support if needed, the respondents most frequently indicated family $(\mathrm{n}=411 ; 81.55 \%)$ or spouse ( $\mathrm{n}=147 ; 29.56 \%)$. One out of ten indicated neighbours $(\mathrm{n}=49 ; 9.72 \%)$, very few would use social care ( $n=11,2.18 \%)$, or other people or institutions $(n=3 ; 0.60 \%)$. Among those who indicated spouses as persons providing support, 73 individuals (14.88\%) would not mark any other option. It is noteworthy that 37 people took advantage of social care ( $7.34 \%$ of the test group). 32 persons in the test group (86.39\% who used social care aid) used only one form of support, 4 (10.81\%) used two forms and 1 (2.70\%) would benefit from three forms of support. The interviewees most frequently got financial aid ( $n=26 ; 70.27 \%)$ or non-financial aid ( $n=14 ; 37.84 \%)$. Care services were used by 1 person (2.70\%) and meal sponsoring by 2 respondents (5.41\%). Additionally, 24 people (64.86\%) claimed that the social care aid was insufficient, 10 people thought it to be sufficient (27.03\%), and 3 people (8.11\%) refrained from answering the question.

It was shown that women, more frequently than men, pointed to the aid received from family $(p<0.001)$. Men would more frequently indicate that their wives were a source of aid ( $p<0.001)$ (fig. 6).

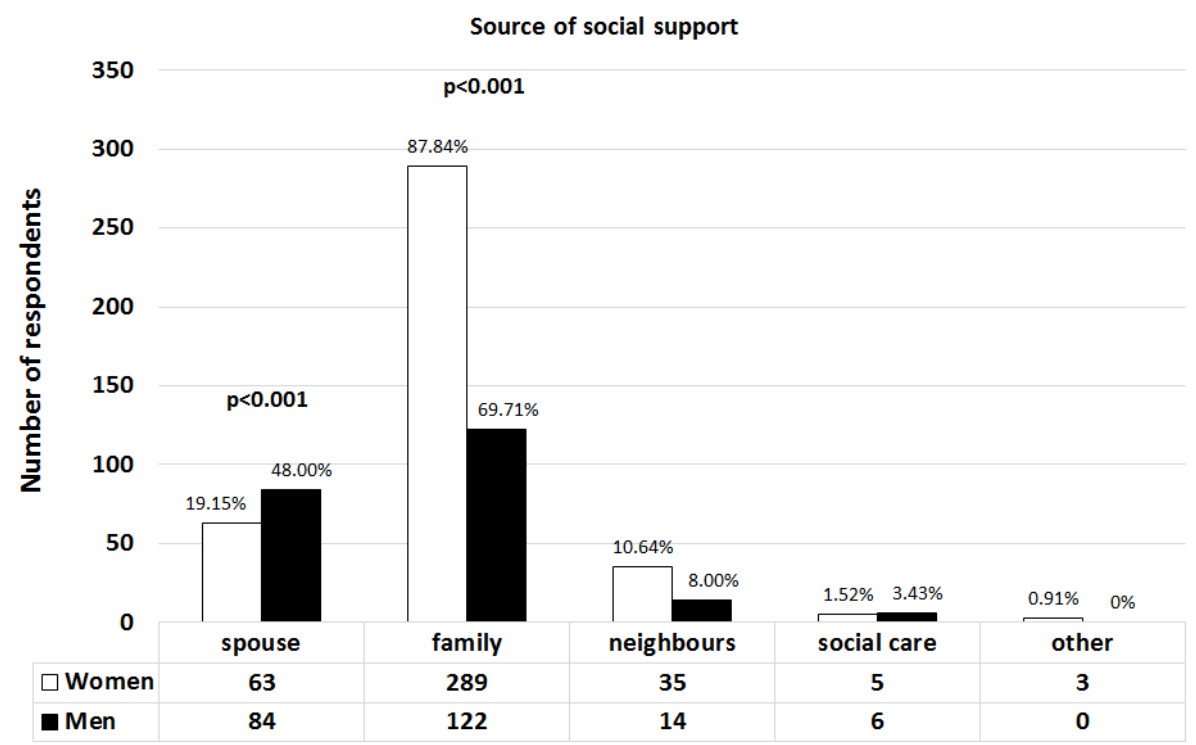

Figure 6. Source of social support vs. sex of respondents $(\mathrm{N}=504)$ 
While comparing various sources of aid, it was shown that women would more frequently take advantage of one $(\mathrm{p}<0.05)$, and men - of two $(\mathrm{p}<0.05)$ sources of support. As for the respondents using social services, there were 19 women (51.35\%) and 18 men (48.65\%). They constituted appropriately 5.78\% of the total number of women and $10.29 \%$ of men in the test group. The way both sexes used the social support was not statistically significant $(\mathrm{p}<0.10)$.

Further, the interviewees who indicated that their spouses were the persons who provided support were younger (average age 75.64) than other respondents and this difference was statistically significant $(\mathrm{p}<0.001)$. Those who used family's support (mean age 77.63 years) were a little older. So were those who relied on social services (77.82 years) and neighbours (78.04 years). These differences, however, were not statistically significant. The highest age mean was visible in persons who used one source of support (77.64). The higher the number of sources of support, the lower the mean age of the interviewees - up to 73.00 (4 sources of support); nonetheless, the observed differences were not statistically significant ( $p>0.10)$.

The age of the respondents using social care services was in the range of 66 to 92 (mean age 77.03, SD=6.83; Median=78). No age differences were observed in the respondents benefiting from social care services ( $\mathrm{n}=37$ ), and the rest of the investigated group $(n=467)(p>0.10)$. As for the state of family relationships, the answers were provided by the most respondents ( $\mathrm{n}=336$; 66.67\%), who would see them as "good". 97 interviewees $(19.25 \%)$ would rate them as "very good". 60 respondents (11.90\%) would see their relationships with families as "neutral" and 11 people (2.18\%) - as "bad". No correlation between sex and the state of family relationships was observed $(p>0.10)$. There was also no correlation between the state of the relationship and age variables $(\mathrm{p}>0.10)$.

\section{Discussion}

A number of demographic studies conducted by various authors have shown that both in Poland and other countries in the world the number of women in older age groups is significantly growing $[9,5,10]$. Following the statistical data, women more often live alone and assess their health condition as worse. Also, the financial benefits they receive are lower than those of men [10].

This tendency of ageing process was also confirmed in our study. In the older age categories, women were dominant, their age was significantly higher than the age of men. Women were also more often widowed and lived alone. However, the analysis of the financial situation and needs satisfied by the provided benefits showed no significant differences between women and men. Both women (54.10\%) and men (48.00\%) claimed that the received benefits did not fully cover their current needs. This may be a consequence of very low pensions and illness benefits in agriculture both for women and men, which, regardless of sex, put seniors residing in rural areas in disadvantageous financial condition.

The housing environment of seniors significantly influences the ageing process. Lack of appropriate adaptations to the needs of seniors, discrimination, lack of or inappropriate support contribute to pathological ageing and disability. By contrast, friendly environment, proper relationships, bonds and support lead to better functional efficiency of seniors, a slower ageing process and reduction of the risk of disability [11]. It is believed that people, regardless of their age, meet most important needs within their family. For older persons, family is the primary source of support and care and the main living activity, where family relationships are a vital source of satisfaction [12].

A number of studies by various authors showed that the elderly residing in rural areas mostly live with their families positively assess the resulting research data family relationships, and seek support and aid mainly from their family [12- 16]. This study confirmed these observations because as it was shown that merely $11.31 \%$ of seniors residing in rural areas lived alone. The remaining ones lived with family (65.28\%) or spouses (23.21\%). A vast majority assessed the family relationship as good (66.67\%) or very good (19.25\%). Only $11.90 \%$ of the respondents acknowledged that the relationships were neutral or bad (2.18\%). Similarly, most people indicated that support can be obtained most frequently in family (81.55\%) or provided by a spouse $(29.17 \%)$.

It is believed that the decisive factors influencing the independent functioning of seniors is due to the housing conditions, which provide safety and independence [17]. In the presented study, most respondents rated their housing conditions as good (46.43\%) or very good (28.17\%), $23.61 \%$ of them saw their housing conditions as average, and only $1.79 \%$ claimed they were bad. It was noticed that people rating own housing conditions as bad and average were older than those assessing them as very good and good.

Based on the research carried out in the multicenter European project COPE, one can say that the care of disabled seniors in their home environment relies mainly on family care [18]. Following the Polish Central Statistical Office (GUS) forecast for years 2008-2035, the size of households will be decreasing (from 2.64 to 2.42 
people per household), the percentage of single households will increase (from $26.9 \%$ to $32.5 \%$ ), two-person households (from 26.5\% to 28.7\%) and childless households (from 65.6\% to 75.8\%). All this will impact family care capabilities negatively and the simultaneously forecasted increase in the number of seniors incapable of independent living will cause that support and help of others will be required [19]. Such circumstances enforce and will enforce a different approach to the elderly in future. Healthcare systems and social care units will have to take care of seniors; thus, causing that new guidelines on seniors' care will have to be compiled and issued [20]. It is of utmost importance that social care provided to seniors should be preceded by detailed identification of their needs and aimed at fulfilling these needs [21].

Previously, the study by Makara-Studzińska [22], based on the research of 250 seniors living in rural areas, revealed that rural areas generally lacked on rehabilitation, treatment and prevention centres in close vicinity to old peoples' homes. The health-related education, promotion of healthy lifestyles and social security are insufficient in rural areas [22]. In our study, we found that as few as 37 respondents (7.34\%) used benefits of social services and the most frequently mentioned ones included: financial aid $(26 ; 70.27 \%$ of all the respondents using social aid) or non-financial aid (14; 37.84\%). Only one person $(2.70 \%)$ took advantage of special care services, and two persons (5.41\%) had their meal sponsored. Moreover, 24 people (64.86 \%) claimed that social care aid was insufficient. Unfortunately, the data provided no correlation of age to sex and social care benefits in the tested groups.

Generally, it may be stated that rural environment is a very specific environment where apart from various advantages, including positive influence of natural environment and good family relationships, there are numerous impediments, namely low financial benefits and limited access to social services. Therefore, the planning of seniors' care in rural areas must necessarily take into account the specificity of living in the agricultural environment. The results suggest there should be better access to social care for seniors residing in rural areas (the most of all the special care services) and such aid should be synchronised with geriatric health care services. All this would enable rational provision of social care support regarding necessary demand.

\section{Conclusions}

1. Older women living in rural areas more frequently live alone, are widowed and have lower educational level than men.

2. All financial benefits do not fully cover current needs of older residents in rural areas.

3. In people of over 65 years living in rural areas, the majority $(81.55 \%)$ indicated the family support and only $2.18 \%$ indicated the social care as the source of support.

\section{References:}

1. Budzinowski R. The problems of people in the old age residing in rural areas and the legal aspects. Ruch Prawniczy, Ekonomiczny i Socjologiczny. 1999; 1: 199-212.

2. Iwański R. Sustainable growth of rural areas and the situation of seniors. Folia Pomeranae Universitatis Technologiae Stetinensis, Oeconomica. 2013; 299: 81-90.

3. Dziechciaż M, Guty E, Wojtowicz A, Filip R. Social and health care needs of elderly people living in the countryside in Poland. Ann Agric Environ Med. 2012; 19(4): 746-750.

4. Bień B. Healthcare of people in the old age in rural areas. Przeg Lek. 2002; 59(4-5): 211-215.

5. Kawczyńska-Butrym Z. The challenges of family: health, sickness, disability, old age. Lublin: Wydawnictwo Matmed; 2008 (in Polish).

6. Theeke LA, Mallow J. Loneliness and quality of life in chronically ill rural older adults. Am J Nurs. 2013; 113(9): 28-37. https://doi.org/10.1097/01.NAJ.0000434169.53750.14

7. Dzięgielewska M. Social and Educational activity in the Old Age. In: Szatur-Jaworska B, Błędowski P, Dzięgielewska M., editors. The basis of social gerontology. Warszawa: Oficyna Wydawnicza Aspra - JR; 2006. p. 161-178 (in Polish).

8. Żak M, Karwat JD, Żak A. Main areas of life limitations of elders and disabled living in rural areas, depending on the level of disability. In: Solecki L., editor. The problems of elders and disabled in agriculture. Lublin: Instytut Medycyny Wsi; 2004. p. 165-173 (in Polish).

9. Bogusz R, Charzyńska-Góra M, Szkuat M, Kocka K, Szadowska-Szlachetka Z. Functional agility of people of over 70 years of age living in rural areas and the need for such care. Medycyna Ogólna i Nauki o Zdrowiu. 2013; 19(4): 517-522. 
10. Błędowski P. Ageing as social problem. Perspectives of demographic ageing of Polish population until 2035. In: Mossakowska M, Więcek A, Błędowski P., editors. Medical, psychological, social and economical aspects of ageing in Poland. Poznań: Termedia Wydawnictwa Medyczne; 2012. p. 11-23 (in Polish).

11. Kilian M. Disabled in society. Polityka Społeczna. 2007; 11-12: 14-18.

12. Szatur-Jaworska B. Family situation and caring needs of the elders in Poland. Studia BAS. 2012; 2(30): 59-76.

13. Szatur-Jaworska B. Family situation and family bonds of the elders and people entering the old age. In: Mossakowska M, Więcek A, Błędowski P., editors. Medical, psychological, social and economical aspects of ageing in Poland. Poznań: Termedia Wydawnictwa Medyczne; 2012. p. 419-448.

14. Dziechciaż M, Guty E, Wojtowicz A, Schabowski J. The need for long-term care among the people in the old age residing in rural areas. Nowiny Lekarskie. 2012; 1(81): 26-30.

15. Borowiak E, Kostka T. The anticipation for caring services of seniors residing in urban and rural areas and caring-nursing institutions. Gerontologia Polska 2010; 18(4): 207-215.

16. Zych A. Human versus ageing. Studies of social gerontology. Katowice: Biblioteka Pracownika Socjalnego; 1990.

17. Bartoszek A, Niezabitowska E, Kucharczyk-Brus B, Niezabitowski M. Housing conditions of seniors - main research outlines. In: Mossakowska M, Więcek A, Błędowski P., editors. Medical, psychological, social and economical aspects of ageing in Poland. Poznań: Termedia Wydawnictwa Medyczne; 2012. p. $511-530$ (in Polish).

18. Mojsa W, Chlebicz S, Małyszko J. The characteristics of patients for long-term nursing care between 20042008 in province of Podlasie. Gerontologia Polska. 2013; 21(1): 18-24.

19. Szymborski J. The demography of ageing society. In: Samoliński B, Raciborski F., editors. Healthy ageing: White Paper. Warszawa: Wydawnictwo Naukowe Scholar; 2013. p. 14-17.

20. Radziewicz-Winnicki I. The meaning of active healthy ageing idea for the system of healthcare. In: Samoliński B, Raciborski F., editors. Healthy ageing: Warszawa: Wydawnictwo Naukowe Scholar; 2013. p. 96-101 (in Polish).

21. Dziechciaż M, Płaszewska-Żywko L, Guty E. Independence of elderly persons living in the rural areas in performing basic and complex everyday activities. Pol J Pub Health. 2010; 120(4): 346-350.

22. Makara-Studzińska M. The analysis of pro-health activities of elders in the rural area. In: Kowaleski JT, Szukalski P., editors. Health condition of seniors in Poland. Medical, social and demographic aspect. Materials of nationwide science seminar between 26-27 June 2000. Łódź: Oficyna Wydawnicza Instytutu Medycyny Pracy im. prof. Jerzego Nofera; 2000. p. 103-108 (in Polish). 